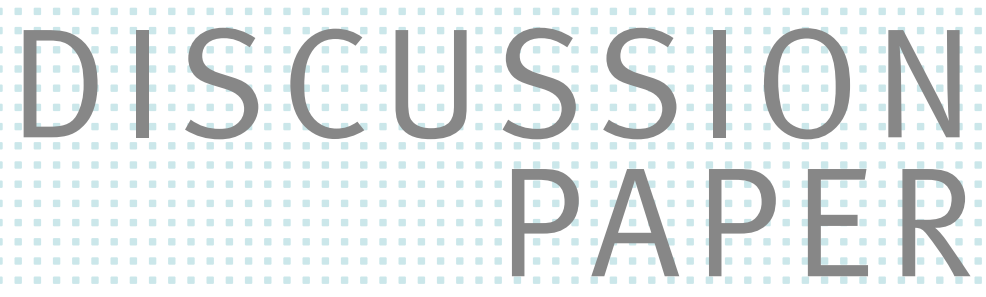

// MARIUS BERGER AND HANNA HOTTENROTT

Public Subsidies and the Sources of Venture Capital 


\title{
Public Subsidies and the Sources of Venture Capital
}

\author{
Marius Berger ${ }^{1,2}$ and Hanna Hottenrott ${ }^{1,2 *}$
}

December 2020

\author{
${ }^{1}$ ZEW - Leibniz Centre for European Economic Research \\ 2 Technical University of Munich, TUM School of Management
}

\begin{abstract}
Research suggests that public subsidies for newly founded firms have a positive effect on follow-on financing, in particular, Venture Capital (VC). This study differentiates between Government VC, Independent VC, Corporate VC, and Business Angels and shows that public subsidies are not relevant for all of these sources. When accounting for firm characteristics that drive both selection into public subsidies as well as into VC financing through econometric matching techniques, we find that subsidies are only linked to Government $\mathrm{VC}$ and Business Angel financing.
\end{abstract}

Key words: Start-up Subsidies, Entrepreneurship Policy, Entrepreneurial Finance, Venture Capital, Business Angels

JEL codes: G24, L26, O25, O31

*Corresponding author address: Technical University of Munich, TUM School of Management, Dept. of Economics \& Policy, Arcisstraße 21, 80333 Munich, Germany, E-mail: hanna.hottenrott@tum.de Acknowledgments: The authors thank participants of virtual research seminars at the Technical University of Munich and the University of Marburg for helpful comments. 


\section{Introduction}

New firms play an important role in knowledge-based economies (van Praag and Versloot, 2007). They contribute to the introduction of new products as well as to the diffusion of new technologies (Audretsch, Link, Sauer and Siegel, 2016). In particular radical innovations are more likely to be implemented by new than by established firms (Acs and Audretsch, 1988; Caggese, 2019). New firms also create jobs (Haltiwanger, Jarmin and Miranda, 2013). The returns to new firm creation, however, are not fully appropriated by the entrepreneur. Social returns may exceed private returns through the value generated by new products or improved processes. Moreover, firms entering markets with novel, complex products are particularly prone to suffer from the liability of newness which can be a barrier to new firm success (Ostgaard and Birley, 1994).

Public support of new firms therefore aims to help to overcome financing constraints. The effectiveness of subsidies for start-ups in achieving this goal has been examined in a series of studies suggesting that direct financial support fosters start-up innovation and growth (Colombo, Giannangeli and Grilli, 2012; Colombo, Grilli and Murtinu, 2011; Howell, 2017; Conti, 2018; Hottenrott and Richstein, 2020). Research further suggests that the effects go beyond direct financial aid by triggering second order effects in terms of access to (follow-on) financing provided by other lenders (Hottenrott, Lins and Lutz, 2018) or investors (Lerner, 1999; Söderblom, Samuelsson, Wiklund and Sandberg, 2015; Howell, 2017; Hottenrott and Richstein, 2020; Zhao and Ziedonis, 2020). These second order effects may explain why initially small amounts of public funding result in measurable effects.

This study contributes to understanding these second order effects by distinguishing the extent to which public support attracts different sources of venture capital (VC) financing. Different investor types pursue different goals and to some investors public support may be more valuable than for others (Hsu, Haynie, Simmons and McKelvie, 2014; Tykvová, 2018). We distinguish between Government Venture Capital (GVC), Independent Venture Capital (IVC), Corporate Venture Capital (CVC), and Business Angels (BA). Using data on 9,743 start-ups founded between 2005 and 2016 in knowledge-intensive sectors in Germany that are potentially of interest to venture capital investors, we show that there is a positive correlation between public subsidies and all sources of VC. When taking into account the selection into subsidy programs, however, the second order financing effect can only be linked to GVC and BA financing.

\section{Public Subsidies and VC}

VC has become increasingly important in the financing of new firms even in countries that traditionally had comparably low levels of VC. The empirical setting for the following study is Germany for which Figure 1 shows that VC financing increased substantially from 2006 to 2016 (left panel). Figure 1 also illustrates that there is a mix of VC providers that became equally important over time. 
Figure 1: Sources of VC
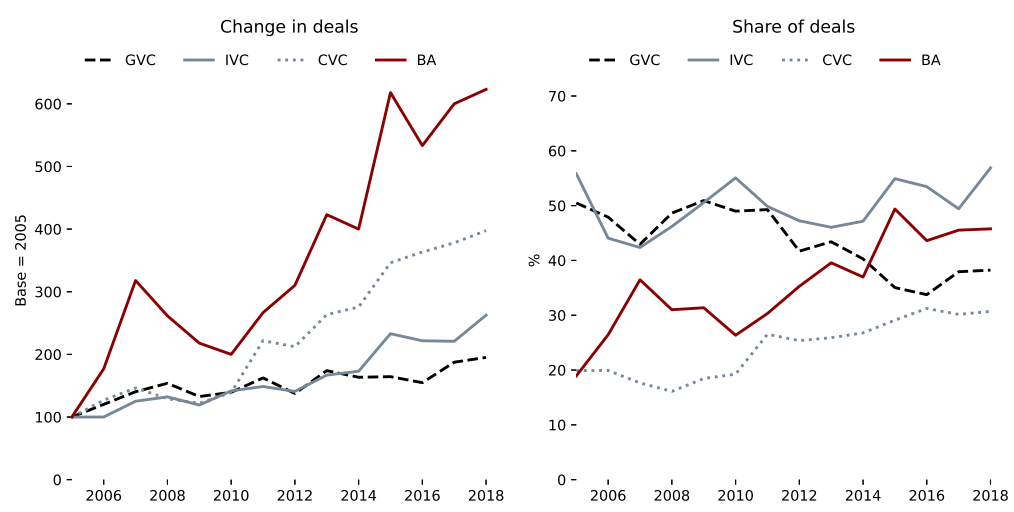

Sources: IAB/ZEW Startup Panel, Bureau van Dijk, Majunke Consulting. Own calculations.

Previous research shows that new firms that receive subsidies are more likely to raise VC funding (Lerner, 1999; Howell, 2017; Conti, 2018; Hottenrott and Richstein, 2020; Zhao and Ziedonis, 2020). Publicly financed startups may appeal to VC investors for at least two reasons. First, public subsidies carry an information value. Second, they finance risky early stage activities. Although VC investors are typically well informed about industry prospects and perform own assessments (Shepherd, 1999), the information value that they extract from public subsidies may depend on the investor type. While it is often argued that subsidies may reveal quality-related information about a firm, the information value could also be related to aspects of regulatory uncertainty and societal returns to the firms' activities. Public funding agencies, that allocate subsidies may have an information advantage about new technologies, their regulation, and their longer-run prospects (Lerner, 1999). Such information should be more valuable to investors who acquire less information through formal due diligence processes or formal networks as is the case for BA (Fiet, 1995). For these investors the information value of subsidies should be relatively higher as they acquire less information ex-ante and often base their investment decisions on heuristic assessments (Van Osnabrugge, 2000; Maxwell, Jeffrey and Lévesque, 2011). Moreover, like GVC, BA may pursue goals other than pure economic profit by investing in firms that fit their mission and their desire to contribute to society (Hsu et al., 2014). Especially GVC and BA may therefore understand the award of a public subsidy as a signal of these prospects.

In addition, Howell (2017) argues that firms use the awarded money to advance their project thereby reducing technological uncertainty, and reach a proof-of-concept stage, making them more attractive to VCs. Similarly, Hottenrott and Richstein (2020) find that when firms receive grants combined with publicly backed loans, the VC probability is higher than in the case of grants alone. Therefore, it may not be the information value alone, but also the funding amount that attracts investors.

How much of these channels matter may depend on the source of VC. For IVC investors 
it is typically the return on investments that matters in the first place (Hsu et al., 2014) and their due diligence may allow them to collect sufficient information so that the subsidy carries little additional information value about technological market prospects, quality of the business model or founder characteristics. The cash inflow from the subsidy may still increase firms' attractiveness as it allows financing of uncertain early stage investments. CVC decisions may also rely on the corporate's own expert knowledge. Moreover, the economic profit of the venture may not be the most important aspect in the CVC objective function. The CVC may pursue strategic goals (Riyanto and Schwienbacher, 2006) which reduces both the information value of subsidies as well as of the uncertainty reducing early stage investment. Public subsidies may still serve as a talent and technology screening device. Corporations may observe grant competitions and participating startups may therefore be simply more visible to CVC funds compared to others.

Previous studies, however, do not distinguish between the sources of VC leaving the question open whether the observed link between the subsidy and $\mathrm{VC}$ is driven by a specific type of investor. Understanding this has implications for assessing the overall impact of start-up subsidies.

\section{Data}

The firm-level data for the analysis stems from the IAB/ZEW Start-up Panel (Fryges, Gottschalk and Kohn, 2009) for the founding cohorts 2008 to 2018, Bureau van Dijk's Zephyr data base as well as from transaction data published by Majunke Consulting. The final sample covers information from 9,743 firms of which $35 \%$ received start-up subsidies and $2.7 \%$ some form of VC. Subsidies include grants, subsidized loans and guarantees. When looking at VC-funding in subsidized versus non-subsidized firms, we see that in more recent founding cohorts, a larger share of subsidized firms received VC (Figure 2). See Appendix A for a detailed data description. Tables A.1 and A.2 summarize the variables. Table 1 present differences between the group of subsidized and non-subsidized start-ups in terms of founder and firm characteristics and shows that the groups differ considerable in their observable characteristics poiting to the importance of accounting for these differences in the following analysis. 
Figure 2: VC investments by founding cohorts

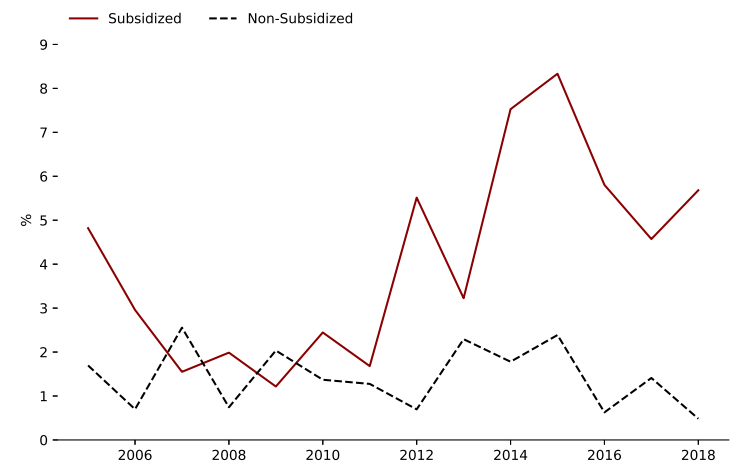

Sources: Bureau van Dijk, Majunke Consulting, Mannheim Startup Panel. Own calculations.

\section{Empirical methodology}

To investigate the link between subsidies and venture capital, we estimate linear probability models such that:

$$
X V C_{i t}=\alpha+\beta S u b s i d y_{i t}+\gamma X_{i t}+\tau_{t}+\phi_{i}+u_{i t},
$$

where $X V C_{i t}$ is an indicator variable that switches to 1 in the year when startups receive their first venture capital investment from one of the investor types in $X V C=$ $\{G V C, B A, I V C, C V C\}$. Subsidy $y_{i t}$ is an indicator variable that switches to 1 in the year when startups receive their first public subsidy, $X_{i t}$ is a set of control variables and $\tau_{t}$ and $\phi_{i}$ are year and company specific fixed factors, of which the latter are unobserved.

We estimate pooled models as well as a within estimator which accounts for unobserved time-constant firm characteristics. Yet, the key variable of interest - subsidy receipt - is not randomly assigned to firms. A correlation between subsidy receipt and VC financing could be due to common drivers of both outcomes rather than a causal link between the two.

To address the selection into the group of subsidized firms, we perform matching techniques (Rubin, 2005). We follow Hottenrott and Richstein (2020) and use a combination of propensity score matching (PSM) and exact matching (EM). See Appendix B for details. Table 1 shows the variables used in the PSM. Additionally, we match exactly on founding year, industry, and sector. The balance of the covariates improves through the matching so that there are no significant differences between treated and control firms anymore. Figure A.1 shows the distributions of propensity scores after matching and Table A.3 shows the balancing of the controls. 
Table 1: Difference in Means of Controls

\begin{tabular}{|c|c|c|c|c|c|c|}
\hline & \multicolumn{6}{|c|}{ Panel A: unmatched } \\
\hline & \multicolumn{2}{|c|}{$\begin{array}{c}\text { Subsidized } \\
\quad \mathrm{N}=3422\end{array}$} & \multicolumn{2}{|c|}{$\begin{array}{l}\text { Non-subsidized } \\
\qquad \mathrm{N}=6321\end{array}$} & \multirow[b]{2}{*}{$\Delta$} & \multirow[b]{2}{*}{$\mathrm{t}$} \\
\hline & Mean & Std. Err. & Mean & Std. Err. & & \\
\hline \multicolumn{7}{|l|}{ Controls } \\
\hline Founder age (log) & 3.680 & 0.216 & 3.710 & 0.252 & 0.029 & 6.05 \\
\hline Team & 0.537 & 0.499 & 0.440 & 0.496 & -0.097 & -9.19 \\
\hline Academic & 0.716 & 0.451 & 0.682 & 0.466 & -0.034 & -3.49 \\
\hline Female & 0.170 & 0.375 & 0.166 & 0.372 & -0.004 & -0.52 \\
\hline Industry experience & 12.950 & 9.290 & 13.739 & 10.309 & 0.789 & 3.85 \\
\hline Founding experience & 0.498 & 0.500 & 0.606 & 0.489 & 0.107 & 10.20 \\
\hline Failure experience & 0.175 & 0.380 & 0.211 & 0.408 & 0.036 & 4.35 \\
\hline Opportunity driven & 0.493 & 0.500 & 0.483 & 0.500 & -0.010 & -0.99 \\
\hline$R \& D$ & 0.520 & 0.500 & 0.403 & 0.491 & -0.117 & -11.11 \\
\hline \multirow[t]{4}{*}{ Patent } & 0.071 & 0.257 & 0.051 & 0.220 & -0.020 & -3.87 \\
\hline & \multicolumn{6}{|c|}{ Panel B: matched } \\
\hline & \multicolumn{2}{|c|}{$\mathrm{N}=2208$} & \multicolumn{2}{|c|}{$\mathrm{N}=1756$} & & \\
\hline & Mean & Std. Err. & Mean & Std. Err. & $\Delta$ & $\mathrm{t}$ \\
\hline Propensity score & 0.255 & 0.151 & 0.254 & 0.149 & 0.001 & 0.215 \\
\hline
\end{tabular}

\section{Results}

Table 2 shows the main estimation results. Panel A shows the results for the unmatched sample, Panels B and C show pooled OLS and fixed effects models on the matched sample, respectively. The first column in Panel $\mathrm{B}$ indicates that receiving a public subsidy more than doubles the probability to receive VC relative to non-recipients (109\%). ${ }^{1}$ Looking at the different sources of $\mathrm{VC}$, we observe that subsidized firms are significantly more likely to receive GVC or BA investments, but not more likely to receive CVC and IVC. This is in contrast to the models on the unmatched sample in which we observe positive correlations with all sources of VC. This result is even more pronounced in the within estimation (Panel C) which additionally accounts for unobserved heterogeneity among firms (Tables A.6-A.4 shows the full estimation results with and without matching). Since the four VC-types may co-occur, we also estimate the four equations jointly and find that the results are robust to this alternative specification (see Tables A.9 and A.10 for regression results and Table A.11 for error correlation across equations). In this specification, we test whether the coefficients for subsidy receipt are significantly different in the GVC versus BA equation and find that the coefficients are not statistically different $\left(\chi^{2}(1)=1.21\right.$, p-value $\left.=0.27\right)$. See Table A.12 for all pair-wise comparisons.

\footnotetext{
${ }^{1}$ The marginal effect of 0.0026 refers to the difference in the predicted probability of VC in both groups. The percentage increase is calculated as $\operatorname{Prob}(\mathrm{VC} \mid \mathrm{Subsidy}) / \operatorname{Prob}(\mathrm{VC} \mid$ No Subsidy $)=(0.0050 / 0.0024-1) \times$ $100 \approx 109$.
} 
Table 2: Results

\begin{tabular}{|c|c|c|c|c|c|}
\hline & \multicolumn{5}{|c|}{ Panel A: POLS (unmatched) } \\
\hline & $\mathrm{VC}$ & GVC & $\mathrm{BA}$ & IVC & CVC \\
\hline $\operatorname{Subsidy}(t)$ & $\begin{array}{c}0.0034^{* * *} \\
(0.0006)\end{array}$ & $\begin{array}{c}0.0029^{* * *} \\
(0.0005)\end{array}$ & $\begin{array}{c}0.0014^{* * *} \\
(0.0004)\end{array}$ & $\begin{array}{c}0.0010^{* * *} \\
(0.0004)\end{array}$ & $\begin{array}{c}0.0007^{* *} \\
(0.0003)\end{array}$ \\
\hline \multirow[t]{2}{*}{ Obs. } & 55052 & 55321 & 55676 & 55599 & 55839 \\
\hline & \multicolumn{5}{|c|}{ Panel B: POLS (matched) } \\
\hline $\operatorname{Subsidy}(t)$ & $\begin{array}{c}0.0026^{* * *} \\
(0.0008)\end{array}$ & $\begin{array}{c}0.0022^{* * *} \\
(0.0007)\end{array}$ & $\begin{array}{c}0.0015^{* * *} \\
(0.0005)\end{array}$ & $\begin{array}{c}0.0002 \\
(0.0006)\end{array}$ & $\begin{array}{c}0.0005 \\
(0.0004)\end{array}$ \\
\hline \multirow[t]{2}{*}{ Obs. } & 24978 & 25105 & 25285 & 25209 & 25327 \\
\hline & \multicolumn{5}{|c|}{ Panel C: Within (matched) } \\
\hline $\operatorname{Subsidy}(t)$ & $\begin{array}{l}0.0058^{* *} \\
(0.0025)\end{array}$ & $\begin{array}{l}0.0042^{* *} \\
(0.0020)\end{array}$ & $\begin{array}{l}0.0031^{*} \\
(0.0018)\end{array}$ & $\begin{array}{c}0.0013 \\
(0.0017)\end{array}$ & $\begin{array}{c}0.0012 \\
(0.0010)\end{array}$ \\
\hline Groups & 3953 & 3955 & 3963 & 3961 & 3961 \\
\hline Obs. & 24978 & 25105 & 25285 & 25209 & 25327 \\
\hline
\end{tabular}

\section{Conclusion}

Previous research suggested that start-ups with public subsidies are more likely to receive VC. Our results confirm this even after accounting for selection effects. However, our results show that this positive relationship exists for GVC and BA financing, but not for VC from other investors. The result that GVC and BA funding is most sensitive to public start-up funding could have three reasons. First, to the extent that public funding agencies are considered knowledgeable, their start-up support may convey a valuable legitimizing endorsement. The information value of a subsidy award may, however, decrease with the degree of ex-ante information acquisition of the financier. Second, additional financial resources matter more to GVC and BA compared to other investors. Third, there is an inherent link between the two sources. In the case of GVC, subsidies could be provided with the explicit hint of the funder to seek GVC. There may also be advantages when pitching for GVC for firms that have previously dealt with public agencies either through learning about their expectations or simply through (personal) connections. Unlike for private VC, public subsidies and GVC could even be conditioned on one another. Yet, the data that we analysed here suggests that the increase in the share of $\mathrm{VC}$ in subsidized firms is largely driven by BA - a source of funding that became considerably more important.

Our results suggest that the second order effects of start-up subsidies are not guaranteed, but may depend on the active investor mix in a country. Finally, we strongly encourage research in other settings in order to understand the generalizability of this result. 


\section{References}

Acs, Z. J. and Audretsch, D. B. (1988), 'Innovation in large and small firms: An empirical analysis', The American Economic Review 78(4), 678-690.

Audretsch, D. B., Link, A. N., Sauer, R. M. and Siegel, D. S. (2016), 'Advancing the economics of entrepreneurship', European Economic Review 86, 1-3.

Caggese, A. (2019), 'Financing constraints, radical versus incremental innovation, and aggregate productivity', American Economic Journal: Macroeconomics 11(2), 275-309.

Colombo, M. G., Giannangeli, S. and Grilli, L. (2012), 'Public subsidies and the employment growth of high-tech start-ups: assessing the impact of selective and automatic support schemes', Industrial and Corporate Change 22(5), 1273-1314.

Colombo, M. G., Grilli, L. and Murtinu, S. (2011), 'R\&d subsidies and the performance of high-tech start-ups', Economics Letters 112(1), 97 - 99.

Conti, A. (2018), 'Entrepreneurial finance and the effects of restrictions on government R\&D subsidies', Organization Science 29(1), 134-153.

Fiet, J. O. (1995), 'Reliance upon informants in the venture capital industry', Journal of Business Venturing 10(3), 195 - 223.

Fryges, H., Gottschalk, S. and Kohn, K. (2009), 'The KfW/ZEW start-up panel: design and research potential', ZEW-Centre for European Economic Research Discussion Paper (09-053).

Haltiwanger, J., Jarmin, R. S. and Miranda, J. (2013), 'Who creates jobs? small versus large versus young', The Review of Economics and Statistics 95(2), 347-361.

Hottenrott, H., Lins, E. and Lutz, E. (2018), 'Public subsidies and new ventures' use of bank loans', Economics of Innovation and New Technology 27(8), 786-808.

Hottenrott, H. and Richstein, R. (2020), 'Start-up subsidies: Does the policy instrument matter?', Research Policy 49(1), 103888.

Howell, S. T. (2017), 'Financing innovation: Evidence from R\&D grants', American Economic Review 107(4), 1136-64.

Hsu, D. K., Haynie, J. M., Simmons, S. A. and McKelvie, A. (2014), 'What matters, matters differently: a conjoint analysis of the decision policies of angel and venture capital investors', Venture Capital 16(1), 1-25.

Lerner, J. (1999), 'The government as venture capitalist: The long-run impact of the SBIR program', The Journal of Business 72(3), 285-318.

Maxwell, A. L., Jeffrey, S. A. and Lévesque, M. (2011), 'Business angel early stage decision making', Journal of Business Venturing 26(2), 212-225.

Ostgaard, T. A. and Birley, S. (1994), 'Personal networks and firm competitive strategy - a strategic or coincidental match?', Journal of Business Venturing 9(4), 281 - 305.

Riyanto, Y. E. and Schwienbacher, A. (2006), 'The strategic use of corporate venture financing for securing demand', Journal of Banking Finance 30(10), 2809 - 2833.

Rubin, D. B. (2005), 'Causal inference using potential outcomes: Design, modeling, decisions', Journal of the American Statistical Association 100(469), 322-331. 
Shepherd, D. A. (1999), 'Venture capitalists' assessment of new venture survival', Management Science 45(5), 621-632.

Söderblom, A., Samuelsson, M., Wiklund, J. and Sandberg, R. (2015), 'Inside the black box of outcome additionality: Effects of early-stage government subsidies on resource accumulation and new venture performance', Research Policy 44(8), 1501 - 1512.

Van Osnabrugge, M. (2000), 'A comparison of business angel and venture capitalist investment procedures: an agency theory-based analysis', Venture Capital: An international Journal of Entrepreneurial Finance 2(2), 91-109.

van Praag, C. M. and Versloot, P. H. (2007), 'What is the value of entrepreneurship? A review of recent research', Small Business Economics 29, 351-382.

Zhao, B. and Ziedonis, R. (2020), 'State governments as financiers of technology startups: Evidence from Michigan's R\&D loan program', Research Policy 49(4), 103926. 


\section{Appendices}

\section{Supplemental Material for 'Public Subsidies and the Sources of Venture Capital'}

\section{A Data description}

We use information from four primary databases to conduct our analysis.

Data on startups. Our primary data source is the IAB/ZEW Startup Panel, ${ }^{2}$ which is based on a yearly survey among startups in Germany, administered by the Institute for Employment Research and ZEW - Leibniz Centre for Europen Economic Research. The sample of startups that enter the survey are drawn as a stratified random sample from the Mannheim Enterprise Panel (MEP), ${ }^{3}$ a comprehensive database of the population of German firms. When startups enter the survey, they are at least one and at most three years old, and remain in the sample until a maximum age of seven years. Importantly for our analysis, it contains detailed information on the use of public subsidies in startup companies. Startups are asked to indicate whether they have received public subsidies in the form of subsidized loans, grants, or guarantees. For the purpose of this paper, we consider all forms of subsidies jointly. ${ }^{4}$ Note that only for companies first surveyed in their founding year we know the exact year of the first subsidy receipt. From these companies we know that $85 \%$ of startups that receive a subsidy, receive it in their year of foundation. For the group of startups for which the founding year and the first reference year are not equal, we assume that they receive their first subsidy in the founding year. We conduct robustness checks to check whether this assumption is material to the results and re-estimate all models only including firms that we observe from the first year onward (see Table A.8).

To control for founder and firm characteristics, we use information on founders' gender, educational background, founding and industry experience, as well as whether firms were founded by a team. In addition we include firms' founding year, their sector of activity and location. The innovation potential is proxied by an indicator for firms R\&D activity and their Intellectual Property (IP) in terms of patents, as well as a variable indicating whether firms were founded based on a concrete business idea.

Venture capital transactions. To identify startups that receive venture capital investments, we use transaction data from two primary data sources. The first is Bureau van Dijk's Zephyr data base which contains information on worldwide M\&A transactions,

\footnotetext{
${ }^{2}$ See Fryges et al. (2009) for details.

${ }^{3}$ The MEP is based on data from creditreform - Germany's largest credit raging agency - and maintained and administered by the ZEW - Leibniz Centre for European Economic Research in Mannheim. For more details on the MEP see Bersch, Gottschalk, Müller and Niefert (2014).

${ }^{4}$ Previous research suggest that there are differences between grants and loans with regard to incentivizing $\mathrm{R} \& \mathrm{D}$ versus tangible investments, but that in terms of their role for $\mathrm{VC}$, both policy tools are quite similar (Hottenrott and Richstein, 2020).
} 
including venture capital transactions. We use information on minority stake acquisitions through venture capital financing in the period from 2005 to 2018, where the target company is located in Germany. Zephyr has been used for a recent large scale research project on venture capital in Europe to identify i.a. German venture capital transactions (Bertoni and Martí, 2011). Zephyr has, however, a limited coverage for German venture capital transactions. We therefore complement the Zephyr data with information from Majunke Consulting, a private equity boutique that collects information on M\&A, private equity, and venture capital transactions in the DACH region. ${ }^{5}$ Majunke's venture capital data start in 2005 and the data set contains all information collected by Majunke up until 2018. We match information on acquirers (i.e. venture investors) and target companies (startups) with the MEP based on names and adresses. We identified $99 \%$ of startups from the Zephyr database and 98\% from Majunke's data applying a fuzzy string matching algorithm on company names and addresses. ${ }^{6}$ Once merged to the MEP, we can link the data to the IAB/ZEW Startup Panel. In a next step, we classified investors into categories, differentiating between independent and various types of captive venture capital investors using information from investors' websites, crunchbase, Bloomberg as well as ownership information from the MEP. For our analysis we distinguish between four different types of venture capital investors, government venture capital (GVC), independent venture capital (IVC), corporate venture capital (CVC), and Business Angels (BA).

Sample. We focus on firms that are potentially relevant for venture capital investments. Research on the venture capital market has shown consistently that venture capital investments are concentrated in certain sectors and certain types of start-ups (Lerner and Nanda, 2020). Therefore, we restrict the sample to knowledge-intensive sectors. That is, we discard startups that are operating in construction, retail and consumer oriented services industries. We also discard startups that are operating as franchise companies or joint-ventures, and keep only startups that are either limited liability companies or incorporations. After the elimination of observations with missing values, the final sample comprises information on 9,743 startups.

\section{B Matching approach}

Matching. We employ a matching procedure that combines propensity score matching and coarsened exact matching (Iacus, King and Porro, 2012). The idea of matching is to find observations that are reasonably comparable thereby adjusting the distribution of pretreatment covariates by either excluding and/or reweighting observations. While exact matching has several desirable properties, like an intuitive interpretation, and an upper bound on the level of imbalance in the matched sample (Iacus, King and Porro, 2011), i.e. the degree of variation between different specifications, it also has well known disadvantages. Most notably exact matching leads to small estimation samples, as it discards

\footnotetext{
${ }^{5}$ The DACH region comprises Germany (D), Austria (A) and Switzerland (CH).

${ }^{6}$ For the fuzzy string matching we used Thorsten Doherr's SearchEngine: https://github.com/ThorstenDoherr/searchengine
} 
any observation that is not within the set of strata defined by coarsened pretreatment covariates of treated observations. This may lead to inefficient estimation.

Our matching algorithm proceeds in the following way: First, we narrow down a set of control observations that must have been active in the year when treated observations received their first subsidy. For those observations, we estimate the propensity score for being treated, i.e. the treatment probability, using the covariates displayed in the upper panel of Table 1, as well as indicators for industry, founding cohort and region. Second, we apply caliper matching on the estimated propensity score, on which we place an additional matching requirement. We only want to match observations that are from the same founding cohort, a similar industry, and are located in a similar region. For those variables we employ an exact matching algorithm. We implement the algorithm using the user written Stata command ultimatch, ${ }^{7}$ which allows to blend different matching procedures.

\section{Additional Tables}

Table A.1: Description of variables.

\begin{tabular}{|c|c|}
\hline Variable Name & Variable Description \\
\hline $\operatorname{Subsidy}(T)$ & The startup has received a subsidy as a grant or loan in any year. \\
\hline$V C(T)$ & $\begin{array}{l}\text { The startup received at least one investment by any venture capital investor in any } \\
\text { year. }\end{array}$ \\
\hline$G V C(T)$ & $\begin{array}{l}\text { The startup received at least one investment by an governmental venture capital } \\
\text { investor in any year. }\end{array}$ \\
\hline $\operatorname{IVC}(T)$ & $\begin{array}{l}\text { The startup received at least one investment by an independent venture capital } \\
\text { investor in any year. }\end{array}$ \\
\hline$C V C(T)$ & $\begin{array}{l}\text { The startup received at least one investment by an corporate venture capital in- } \\
\text { vestor in any year. }\end{array}$ \\
\hline$B A(T)$ & The startup received at least one investment by an angel investor in any year. \\
\hline Startup age at $V C(1)$ & Age of the startup at first VC financing round. \\
\hline Startup age & Age of the startup in years. \\
\hline Founder age & Age of the founders at foundation, for teams it is the average founder age. \\
\hline Team & The startup was founded by more than one person. \\
\hline Academic & At least one founder has a university degree. \\
\hline Female & At least one founder is female. \\
\hline Industry experience & Years of industry experience at foundation. \\
\hline Founding experience & At least one founder has previously founded a company. \\
\hline Failure experience & At least one founder has failed before. \\
\hline Opportunity driven & The startup was founded to realize a business idea. \\
\hline$R \mathscr{E} D(T)$ & The startup has conducted research and/or development activity in any year. \\
\hline Patent & The startup held a patent at foundation. \\
\hline Founding year & The startup's year of foundation. \\
\hline Industry & The main industry the startup operates in. \\
\hline Region & The startups business location. \\
\hline
\end{tabular}

Notes: All of the variables used are binary variables. Except for Industry, Region and Founding Year, which are categorical variables and industry experience and founder age which is measured in years.

\footnotetext{
${ }^{7}$ The command was developed by Thorsten Doherr: https://github.com/ThorstenDoherr/ultimatch
} 
Table A.2: Summary of variables

\begin{tabular}{|c|c|c|c|c|c|}
\hline & Firm Obs. & Mean & Std. Err. & Min. & Max. \\
\hline $\operatorname{Subsidy}(T)$ & 9743 & 0.351 & 0.477 & 0 & 1 \\
\hline \multicolumn{6}{|l|}{ Venture Capital } \\
\hline$V C(T)$ & 9743 & 0.027 & 0.161 & 0 & 1 \\
\hline$G V C(T)$ & 9743 & 0.018 & 0.135 & 0 & 1 \\
\hline$B A(T)$ & 9743 & 0.012 & 0.111 & 0 & 1 \\
\hline$I V C(T)$ & 9743 & 0.012 & 0.108 & 0 & 1 \\
\hline$C V C(T)$ & 9743 & 0.006 & 0.079 & 0 & 1 \\
\hline Startup age at $V C(1)$ & 261 & 1.632 & 1.733 & 0 & 10 \\
\hline \multicolumn{6}{|l|}{ Founders } \\
\hline Founder age & 9743 & 41.573 & 9.744 & 17 & 95 \\
\hline Team & 9743 & 0.474 & 0.499 & 0 & 1 \\
\hline Academic & 9743 & 0.694 & 0.461 & 0 & 1 \\
\hline Female & 9743 & 0.167 & 0.373 & 0 & 1 \\
\hline Industry experience & 9743 & 13.462 & 9.969 & 0 & 59 \\
\hline Founding experience & 9743 & 0.568 & 0.495 & 0 & 1 \\
\hline Failure experience & 9743 & 0.198 & 0.399 & 0 & 1 \\
\hline Opportunity driven & 9743 & 0.486 & 0.500 & 0 & 1 \\
\hline$R \& D(T)$ & 9743 & 0.543 & 0.498 & 0 & 1 \\
\hline Patent & 9743 & 0.058 & 0.234 & 0 & 1 \\
\hline \multicolumn{6}{|l|}{ Industry } \\
\hline Hightech manufacturing & 9743 & 0.201 & 0.401 & 0 & 1 \\
\hline Hightech services \& Software & 9743 & 0.455 & 0.498 & 0 & 1 \\
\hline Nontech manufacturing & 9743 & 0.131 & 0.337 & 0 & 1 \\
\hline B2B \& Knowledge-int. services & 9743 & 0.213 & 0.409 & 0 & 1 \\
\hline \multicolumn{6}{|l|}{ Region } \\
\hline West Germany & 9743 & 0.824 & 0.381 & 0 & 1 \\
\hline Berlin & 9743 & 0.062 & 0.240 & 0 & 1 \\
\hline East Germany & 9743 & 0.114 & 0.318 & 0 & 1 \\
\hline
\end{tabular}

Notes: Firm Obs. refers to the number of firms observed in the sample. The observation period per firm varies depending on the founding year and the corresponding years in which we observe the firm (the minimum number of observation periods is 1 year and the maximum is 12 years, the median is 5 years). Subsidy $(T)$ comprises different types of public subsidies including grants (77\% of subs. firms), subsidized loans (43\% of subs. firms) and public guarantees (18\% of subs. firms). 
Table A.3: Difference in Means of Controls (before and after matching)

\begin{tabular}{|c|c|c|c|c|c|c|}
\hline & \multicolumn{6}{|c|}{ Panel B: matched } \\
\hline & \multicolumn{2}{|c|}{$\begin{array}{l}\text { Subsidized } \\
\qquad N=2208\end{array}$} & \multicolumn{2}{|c|}{$\begin{array}{l}\text { Non-subsidized } \\
\qquad \mathrm{N}=1756\end{array}$} & \multirow[b]{2}{*}{$\Delta$} & \multirow[b]{2}{*}{$\mathrm{t}$} \\
\hline & Mean & Std. Err. & Mean & Std. Err. & & \\
\hline \multicolumn{7}{|l|}{ Controls } \\
\hline Founder age (log) & 3.691 & 0.214 & 3.691 & 0.242 & -0.001 & -0.075 \\
\hline Team & 0.518 & 0.500 & 0.506 & 0.500 & 0.012 & 0.619 \\
\hline Academic & 0.711 & 0.454 & 0.711 & 0.453 & -0.000 & -0.027 \\
\hline Female & 0.162 & 0.369 & 0.173 & 0.378 & -0.010 & -0.698 \\
\hline Industry experience & 13.591 & 9.304 & 13.675 & 10.233 & -0.084 & -0.220 \\
\hline Founding experience & 0.521 & 0.500 & 0.529 & 0.499 & -0.009 & -0.451 \\
\hline Failure experience & 0.183 & 0.386 & 0.170 & 0.376 & 0.012 & 0.884 \\
\hline Opportunity driven & 0.482 & 0.500 & 0.480 & 0.500 & 0.002 & 0.119 \\
\hline$R \& D$ & 0.537 & 0.499 & 0.547 & 0.498 & -0.010 & -0.532 \\
\hline Patent & 0.066 & 0.248 & 0.063 & 0.243 & 0.003 & 0.290 \\
\hline Propensity score & 0.255 & 0.151 & 0.254 & 0.149 & 0.001 & 0.215 \\
\hline
\end{tabular}

Notes: Panel $\boldsymbol{B}$ shows the means, and differences in means ( $\Delta)$ after balancing. Differences in means are the estimated coefficients of a weighted univariate regression of the control variable on the treatment status. The regression weights are the balancing weights obtained from the matching procedure described in section $B$. The standard errors and t-values are calculated under the assumption of heteroskedasticity. 
Table A.4: Unmatched pooled models results

\begin{tabular}{|c|c|c|c|c|c|}
\hline & $\mathrm{VC}$ & GVC & $\mathrm{BA}$ & IVC & $\mathrm{CVC}$ \\
\hline $\operatorname{Subsidy}(t)$ & $\begin{array}{c}0.0034^{* * *} \\
(0.0006)\end{array}$ & $\begin{array}{c}0.0029^{* * *} \\
(0.0005)\end{array}$ & $\begin{array}{c}0.0014^{* * *} \\
(0.0004)\end{array}$ & $\begin{array}{c}0.0010^{* * *} \\
(0.0004)\end{array}$ & $\begin{array}{c}0.0007^{* *} \\
(0.0003)\end{array}$ \\
\hline Startup age (log) & $\begin{array}{c}-0.0044^{* * *} \\
(0.0004)\end{array}$ & $\begin{array}{c}-0.0034^{* * *} \\
(0.0004)\end{array}$ & $\begin{array}{c}-0.0017^{* * *} \\
(0.0003)\end{array}$ & $\begin{array}{c}-0.0009^{* * *} \\
(0.0002)\end{array}$ & $\begin{array}{c}-0.0007^{* * *} \\
(0.0002)\end{array}$ \\
\hline Founder age (log) & $\begin{array}{c}-0.0060^{* * *} \\
(0.0012)\end{array}$ & $\begin{array}{c}-0.0034^{* * *} \\
(0.0010)\end{array}$ & $\begin{array}{c}-0.0036^{* * *} \\
(0.0009)\end{array}$ & $\begin{array}{c}-0.0026^{* * *} \\
(0.0009)\end{array}$ & $\begin{array}{c}-0.0018^{* * *} \\
(0.0006)\end{array}$ \\
\hline Team & $\begin{array}{c}0.0039^{* * *} \\
(0.0006)\end{array}$ & $\begin{array}{c}0.0029^{* * *} \\
(0.0005)\end{array}$ & $\begin{array}{c}0.0013^{* * *} \\
(0.0004)\end{array}$ & $\begin{array}{c}0.0016^{* * *} \\
(0.0004)\end{array}$ & $\begin{array}{c}0.0007^{* * *} \\
(0.0003)\end{array}$ \\
\hline Academic & $\begin{array}{c}0.0030^{* * *} \\
(0.0004)\end{array}$ & $\begin{array}{c}0.0021^{* * *} \\
(0.0003)\end{array}$ & $\begin{array}{c}0.0013^{* * *} \\
(0.0002)\end{array}$ & $\begin{array}{c}0.0013^{* * *} \\
(0.0002)\end{array}$ & $\begin{array}{l}0.0004^{* *} \\
(0.0002)\end{array}$ \\
\hline Female & $\begin{array}{l}-0.0013^{*} \\
(0.0008)\end{array}$ & $\begin{array}{l}-0.0011^{*} \\
(0.0006)\end{array}$ & $\begin{array}{c}0.0002 \\
(0.0006)\end{array}$ & $\begin{array}{l}-0.0005 \\
(0.0005)\end{array}$ & $\begin{array}{c}-0.0002 \\
(0.0003)\end{array}$ \\
\hline Industry experience & $\begin{array}{c}-0.0001^{* * *} \\
(0.0000)\end{array}$ & $\begin{array}{c}-0.0001^{* * *} \\
(0.0000)\end{array}$ & $\begin{array}{c}-0.0001^{* * *} \\
(0.0000)\end{array}$ & $\begin{array}{c}-0.0000^{* *} \\
(0.0000)\end{array}$ & $\begin{array}{c}-0.0000^{* * *} \\
(0.0000)\end{array}$ \\
\hline Founding experience & $\begin{array}{l}-0.0008 \\
(0.0006)\end{array}$ & $\begin{array}{c}-0.0010^{*} \\
(0.0005)\end{array}$ & $\begin{array}{l}-0.0001 \\
(0.0004)\end{array}$ & $\begin{array}{c}0.0006 \\
(0.0004)\end{array}$ & $\begin{array}{l}-0.0000 \\
(0.0003)\end{array}$ \\
\hline Failure experience & $\begin{array}{c}0.0004 \\
(0.0008)\end{array}$ & $\begin{array}{l}0.0012^{*} \\
(0.0007)\end{array}$ & $\begin{array}{l}-0.0002 \\
(0.0005)\end{array}$ & $\begin{array}{l}-0.0004 \\
(0.0006)\end{array}$ & $\begin{array}{c}0.0001 \\
(0.0004)\end{array}$ \\
\hline Opportunity driven & $\begin{array}{c}0.0016^{* * *} \\
(0.0006)\end{array}$ & $\begin{array}{l}0.0010^{* *} \\
(0.0005)\end{array}$ & $\begin{array}{c}0.0006 \\
(0.0004)\end{array}$ & $\begin{array}{c}0.0006^{*} \\
(0.0004)\end{array}$ & $\begin{array}{c}0.0002 \\
(0.0003)\end{array}$ \\
\hline$R \& D$ & $\begin{array}{c}0.0042^{* * *} \\
(0.0006)\end{array}$ & $\begin{array}{c}0.0031^{* * *} \\
(0.0005)\end{array}$ & $\begin{array}{c}0.0024^{* * *} \\
(0.0004)\end{array}$ & $\begin{array}{c}0.0017^{* * *} \\
(0.0004)\end{array}$ & $\begin{array}{c}0.0011^{* * *} \\
(0.0003)\end{array}$ \\
\hline Patent & $\begin{array}{c}0.0004 \\
(0.0014)\end{array}$ & $\begin{array}{c}0.0011 \\
(0.0013)\end{array}$ & $\begin{array}{c}0.0003 \\
(0.0009)\end{array}$ & $\begin{array}{l}-0.0005 \\
(0.0008)\end{array}$ & $\begin{array}{c}0.0001 \\
(0.0006)\end{array}$ \\
\hline Year FE & Yes & Yes & Yes & Yes & Yes \\
\hline Industry FE & Yes & Yes & Yes & Yes & Yes \\
\hline Region FE & Yes & Yes & Yes & Yes & Yes \\
\hline$R 2$ & 0.010 & 0.008 & 0.005 & 0.004 & 0.003 \\
\hline Obs. & 55052 & 55321 & 55676 & 55599 & 55839 \\
\hline
\end{tabular}

Standard errors in parentheses, clustered at the firm level.

${ }^{*} p<0.10,{ }^{* *} p<0.05,{ }^{* * *} p<0.01$ 
Table A.5: Matched pooled models results

\begin{tabular}{|c|c|c|c|c|c|}
\hline & $\mathrm{VC}$ & GVC & $\mathrm{BA}$ & IVC & $\mathrm{CVC}$ \\
\hline $\operatorname{Subsidy}(t)$ & $\begin{array}{c}0.0026^{* * *} \\
(0.0008)\end{array}$ & $\begin{array}{c}0.0022^{* * *} \\
(0.0007)\end{array}$ & $\begin{array}{c}0.0015^{* * *} \\
(0.0005)\end{array}$ & $\begin{array}{c}0.0002 \\
(0.0006)\end{array}$ & $\begin{array}{c}0.0005 \\
(0.0004)\end{array}$ \\
\hline Startup age (log) & $\begin{array}{c}-0.0047^{* * *} \\
(0.0007)\end{array}$ & $\begin{array}{c}-0.0035^{* * *} \\
(0.0006)\end{array}$ & $\begin{array}{c}-0.0019^{* * *} \\
(0.0004)\end{array}$ & $\begin{array}{l}-0.0006 \\
(0.0005)\end{array}$ & $\begin{array}{c}-0.0008^{* *} \\
(0.0003)\end{array}$ \\
\hline Founder age (log) & $\begin{array}{c}-0.0072^{* * *} \\
(0.0021)\end{array}$ & $\begin{array}{c}-0.0044^{* * *} \\
(0.0017)\end{array}$ & $\begin{array}{c}-0.0047^{* * *} \\
(0.0013)\end{array}$ & $\begin{array}{c}-0.0036^{* *} \\
(0.0016)\end{array}$ & $\begin{array}{c}-0.0030^{* * *} \\
(0.0011)\end{array}$ \\
\hline Team & $\begin{array}{c}0.0023^{* *} \\
(0.0010)\end{array}$ & $\begin{array}{c}0.0019^{* *} \\
(0.0008)\end{array}$ & $\begin{array}{c}0.0003 \\
(0.0006)\end{array}$ & $\begin{array}{c}0.0010 \\
(0.0006)\end{array}$ & $\begin{array}{c}0.0006 \\
(0.0004)\end{array}$ \\
\hline Academic & $\begin{array}{c}0.0033^{* * *} \\
(0.0005)\end{array}$ & $\begin{array}{c}0.0021^{* * *} \\
(0.0005)\end{array}$ & $\begin{array}{c}0.0013^{* * *} \\
(0.0004)\end{array}$ & $\begin{array}{c}0.0016^{* * *} \\
(0.0005)\end{array}$ & $\begin{array}{c}0.0008^{* * *} \\
(0.0003)\end{array}$ \\
\hline Female & $\begin{array}{l}-0.0018 \\
(0.0011)\end{array}$ & $\begin{array}{l}-0.0011 \\
(0.0010)\end{array}$ & $\begin{array}{c}0.0000 \\
(0.0008)\end{array}$ & $\begin{array}{c}-0.0014^{* *} \\
(0.0006)\end{array}$ & $\begin{array}{c}-0.0009^{* *} \\
(0.0004)\end{array}$ \\
\hline Industry experience & $\begin{array}{c}-0.0001^{* *} \\
(0.0000)\end{array}$ & $\begin{array}{c}-0.0001^{*} \\
(0.0000)\end{array}$ & $\begin{array}{l}-0.0000 \\
(0.0000)\end{array}$ & $\begin{array}{l}-0.0000 \\
(0.0000)\end{array}$ & $\begin{array}{l}-0.0000^{*} \\
(0.0000)\end{array}$ \\
\hline Founding experience & $\begin{array}{l}-0.0013 \\
(0.0010)\end{array}$ & $\begin{array}{c}-0.0017^{* *} \\
(0.0008)\end{array}$ & $\begin{array}{l}-0.0009 \\
(0.0006)\end{array}$ & $\begin{array}{c}0.0008 \\
(0.0007)\end{array}$ & $\begin{array}{c}0.0000 \\
(0.0004)\end{array}$ \\
\hline Failure experience & $\begin{array}{c}0.0006 \\
(0.0013)\end{array}$ & $\begin{array}{c}0.0011 \\
(0.0011)\end{array}$ & $\begin{array}{c}0.0006 \\
(0.0007)\end{array}$ & $\begin{array}{c}0.0007 \\
(0.0014)\end{array}$ & $\begin{array}{l}-0.0000 \\
(0.0006)\end{array}$ \\
\hline Opportunity driven & $\begin{array}{l}0.0022^{* *} \\
(0.0008)\end{array}$ & $\begin{array}{c}0.0021^{* * *} \\
(0.0007)\end{array}$ & $\begin{array}{c}0.0006 \\
(0.0005)\end{array}$ & $\begin{array}{c}0.0004 \\
(0.0007)\end{array}$ & $\begin{array}{c}0.0002 \\
(0.0004)\end{array}$ \\
\hline$R \& D$ & $\begin{array}{c}0.0040^{* * *} \\
(0.0007)\end{array}$ & $\begin{array}{c}0.0032^{* * *} \\
(0.0005)\end{array}$ & $\begin{array}{c}0.0025^{* * *} \\
(0.0005)\end{array}$ & $\begin{array}{c}0.0013^{* *} \\
(0.0006)\end{array}$ & $\begin{array}{c}0.0004 \\
(0.0004)\end{array}$ \\
\hline Patent & $\begin{array}{c}0.0023 \\
(0.0023)\end{array}$ & $\begin{array}{c}0.0028 \\
(0.0022)\end{array}$ & $\begin{array}{c}0.0002 \\
(0.0011)\end{array}$ & $\begin{array}{c}0.0005 \\
(0.0017)\end{array}$ & $\begin{array}{c}0.0004 \\
(0.0008)\end{array}$ \\
\hline Year FE & Yes & Yes & Yes & Yes & Yes \\
\hline Industry FE & Yes & Yes & Yes & Yes & Yes \\
\hline Region FE & Yes & Yes & Yes & Yes & Yes \\
\hline$R 2$ & 0.009 & 0.007 & 0.005 & 0.004 & 0.003 \\
\hline Obs. & 24978 & 25105 & 25285 & 25209 & 25327 \\
\hline
\end{tabular}

Standard errors in parentheses, clustered at the firm level.

${ }^{*} p<0.10,{ }^{* *} p<0.05,{ }^{* * *} p<0.01$ 
Table A.6: Unmatched within estimation results

\begin{tabular}{lccccc}
\hline & VC & GVC & BA & IVC & CVC \\
\hline Subsidy(t) & $0.0049^{* *}$ & 0.0029 & 0.0025 & 0.0023 & 0.0006 \\
& $(0.0023)$ & $(0.0018)$ & $(0.0017)$ & $(0.0017)$ & $(0.0009)$ \\
Startup age (log) & $0.0089^{* * *}$ & $0.0063^{* * *}$ & $0.0044^{* * *}$ & $0.0036^{* * *}$ & $0.0023^{* * *}$ \\
& $(0.0009)$ & $(0.0007)$ & $(0.0006)$ & $(0.0006)$ & $(0.0004)$ \\
R\&D & $0.0064^{* * *}$ & $0.0056^{* * *}$ & $0.0033^{* * *}$ & $0.0027^{* * *}$ & 0.0011 \\
& $(0.0015)$ & $(0.0013)$ & $(0.0011)$ & $(0.0010)$ & $(0.0007)$ \\
\hline Firm FE & Yes & Yes & Yes & Yes & Yes \\
Year FE & Yes & Yes & Yes & Yes & \\
\hline R2 & 0.006 & 0.005 & 0.003 & 0.003 & 0.002 \\
Groups & 9727 & 9731 & 9739 & 9738 & 9740 \\
Obs. & 55052 & 55321 & 55676 & 55599 & 55839 \\
\hline
\end{tabular}

Standard errors in parentheses, clustered at the firm level.

${ }^{*} p<0.10,{ }^{* *} p<0.05,{ }^{* * *} p<0.01$

Table A.7: Matched within estimation results

\begin{tabular}{lccccc}
\hline & VC & GVC & BA & IVC & CVC \\
\hline Subsidy(t) & $0.0058^{* *}$ & $0.0042^{* *}$ & $0.0031^{*}$ & 0.0013 & 0.0012 \\
& $(0.0025)$ & $(0.0020)$ & $(0.0018)$ & $(0.0017)$ & $(0.0010)$ \\
Startup age (log) & $0.0092^{* * *}$ & $0.0068^{* * *}$ & $0.0051^{* * *}$ & $0.0036^{* * *}$ & $0.0026^{* * *}$ \\
& $(0.0016)$ & $(0.0013)$ & $(0.0011)$ & $(0.0011)$ & $(0.0008)$ \\
R\&D & 0.0014 & 0.0016 & $-0.0019^{* *}$ & 0.0001 & $-0.0016^{* * *}$ \\
& $(0.0025)$ & $(0.0023)$ & $(0.0008)$ & $(0.0013)$ & $(0.0004)$ \\
\hline Firm FE & Yes & Yes & Yes & Yes & Yes \\
Year FE & Yes & Yes & Yes & Yes & Yes \\
\hline R2 & 0.005 & 0.004 & 0.003 & 0.003 & 0.002 \\
Groups & 3953 & 3955 & 3963 & 3961 & 3961 \\
Obs. & 24978 & 25105 & 25285 & 25209 & 25327 \\
\hline
\end{tabular}

Standard errors in parentheses, clustered at the firm level.

${ }^{*} p<0.10,{ }^{* *} p<0.05,{ }^{* * *} p<0.01$ 
Table A.8: Robustness test: Timing assumption

\begin{tabular}{lccccc}
\hline & \multicolumn{5}{c}{ Panel A: POLS (unmatched) } \\
\cline { 2 - 6 } & VC & GVC & BA & IVC & CVC \\
\hline Subsidy $(t)$ & $0.0022^{* * *}$ & $0.0020^{* * *}$ & $0.0009^{*}$ & 0.0002 & 0.0005 \\
& $(0.0008)$ & $(0.0007)$ & $(0.0005)$ & $(0.0005)$ & $(0.0004)$ \\
Obs. & 30962 & 31128 & 31216 & 31212 & 31324 \\
\hline \multirow{5}{*}{ Subsidy(t) } & $0.0029^{* * *}$ & $0.0025^{* * *}$ & $0.0013^{*}$ & 0.0005 & 0.0006 \\
& $(0.0009)$ & $(0.0008)$ & $(0.0007)$ & $(0.0005)$ & $(0.0004)$ \\
Obs. & 19698 & 19798 & 19847 & 19865 & 19913 \\
\hline
\end{tabular}

Standard errors in parentheses, clustered at the firm level.

${ }^{*} p<0.10,{ }^{* *} p<0.05,{ }^{* * *} p<0.01$

Panels A and B include year, industry and region fixed effects, and firm controls.

The sample includes only startups that enter the sample in their first year of operation.

Table A.9: Unmatched seemingly unrelated regression results

\begin{tabular}{|c|c|c|c|c|}
\hline & GVC & $\mathrm{BA}$ & IVC & CVC \\
\hline $\operatorname{Subsidy}(t)$ & $\begin{array}{c}0.0031^{* * *} \\
(0.0006)\end{array}$ & $\begin{array}{c}0.0015^{* * *} \\
(0.0004)\end{array}$ & $\begin{array}{c}0.0010^{* *} \\
(0.0004)\end{array}$ & $\begin{array}{c}0.0007^{* *} \\
(0.0003)\end{array}$ \\
\hline Startup age (log) & $\begin{array}{c}-0.0033^{* * *} \\
(0.0004)\end{array}$ & $\begin{array}{c}-0.0017^{* * *} \\
(0.0003)\end{array}$ & $\begin{array}{c}-0.0009^{* * *} \\
(0.0002)\end{array}$ & $\begin{array}{c}-0.0007^{* * *} \\
(0.0002)\end{array}$ \\
\hline Founder age (log) & $\begin{array}{c}-0.0034^{* * *} \\
(0.0012)\end{array}$ & $\begin{array}{c}-0.0040^{* * *} \\
(0.0010)\end{array}$ & $\begin{array}{c}-0.0027^{* * *} \\
(0.0009)\end{array}$ & $\begin{array}{c}-0.0019^{* * *} \\
(0.0006)\end{array}$ \\
\hline Team & $\begin{array}{c}0.0031^{* * *} \\
(0.0005)\end{array}$ & $\begin{array}{c}0.0014^{* * *} \\
(0.0004)\end{array}$ & $\begin{array}{c}0.0016^{* * *} \\
(0.0004)\end{array}$ & $\begin{array}{c}0.0007^{* * *} \\
(0.0003)\end{array}$ \\
\hline Academic & $\begin{array}{c}0.0022^{* * *} \\
(0.0003)\end{array}$ & $\begin{array}{c}0.0013^{* * *} \\
(0.0003)\end{array}$ & $\begin{array}{c}0.0013^{\text {*** }} \\
(0.0002)\end{array}$ & $\begin{array}{l}0.0004^{* *} \\
(0.0002)\end{array}$ \\
\hline Female & $\begin{array}{l}-0.0009 \\
(0.0007)\end{array}$ & $\begin{array}{c}0.0002 \\
(0.0006)\end{array}$ & $\begin{array}{l}-0.0005 \\
(0.0005)\end{array}$ & $\begin{array}{l}-0.0002 \\
(0.0003)\end{array}$ \\
\hline Industry experience & $\begin{array}{c}-0.0001^{* * *} \\
(0.0000)\end{array}$ & $\begin{array}{c}-0.0001^{* * *} \\
(0.0000)\end{array}$ & $\begin{array}{c}-0.0000^{* *} \\
(0.0000)\end{array}$ & $\begin{array}{c}-0.0000^{* * *} \\
(0.0000)\end{array}$ \\
\hline Founding experience & $\begin{array}{c}-0.0012^{* *} \\
(0.0006)\end{array}$ & $\begin{array}{c}0.0000 \\
(0.0005)\end{array}$ & $\begin{array}{c}0.0007 \\
(0.0004)\end{array}$ & $\begin{array}{l}-0.0000 \\
(0.0003)\end{array}$ \\
\hline Failure experience & $\begin{array}{c}0.0016^{* *} \\
(0.0008)\end{array}$ & $\begin{array}{l}-0.0002 \\
(0.0006)\end{array}$ & $\begin{array}{l}-0.0004 \\
(0.0006)\end{array}$ & $\begin{array}{c}0.0001 \\
(0.0004)\end{array}$ \\
\hline Opportunity driven & $\begin{array}{l}0.0011^{* *} \\
(0.0005)\end{array}$ & $\begin{array}{c}0.0006 \\
(0.0004)\end{array}$ & $\begin{array}{c}0.0007^{*} \\
(0.0004)\end{array}$ & $\begin{array}{c}0.0002 \\
(0.0003)\end{array}$ \\
\hline$R \& D$ & $\begin{array}{c}0.0034^{* * *} \\
(0.0005)\end{array}$ & $\begin{array}{c}0.0026^{* * *} \\
(0.0004)\end{array}$ & $\begin{array}{c}0.0018^{* * *} \\
(0.0004)\end{array}$ & $\begin{array}{c}0.0012^{* * *} \\
(0.0003)\end{array}$ \\
\hline Patent & $\begin{array}{c}0.0012 \\
(0.0014)\end{array}$ & $\begin{array}{c}0.0002 \\
(0.0009)\end{array}$ & $\begin{array}{l}-0.0006 \\
(0.0008)\end{array}$ & $\begin{array}{c}0.0001 \\
(0.0006)\end{array}$ \\
\hline Obs. & 55977 & & & \\
\hline
\end{tabular}

Standard errors in parentheses, clustered at the firm level.

Year, industry and region fixed effects, and firm controls included.

${ }^{*} p<0.10,{ }^{* *} p<0.05,{ }^{* * *} p<0.01$ 
Table A.10: Matched seemingly unrelated regression results

\begin{tabular}{|c|c|c|c|c|}
\hline & GVC & BA & IVC & CVC \\
\hline $\operatorname{Subsidy}(t)$ & $\begin{array}{c}0.0023^{* * *} \\
(0.0008)\end{array}$ & $\begin{array}{c}0.0016^{* * *} \\
(0.0006)\end{array}$ & $\begin{array}{c}0.0002 \\
(0.0006)\end{array}$ & $\begin{array}{c}0.0006 \\
(0.0004)\end{array}$ \\
\hline Startup age (log) & $\begin{array}{c}-0.0035^{* * *} \\
(0.0006)\end{array}$ & $\begin{array}{c}-0.0018^{* * *} \\
(0.0004)\end{array}$ & $\begin{array}{l}-0.0006 \\
(0.0005)\end{array}$ & $\begin{array}{c}-0.0007^{* *} \\
(0.0003)\end{array}$ \\
\hline Founder age (log) & $\begin{array}{c}-0.0049^{* *} \\
(0.0019)\end{array}$ & $\begin{array}{c}-0.0053^{* * *} \\
(0.0015)\end{array}$ & $\begin{array}{c}-0.0040^{* *} \\
(0.0018)\end{array}$ & $\begin{array}{c}-0.0032^{* * *} \\
(0.0011)\end{array}$ \\
\hline Team & $\begin{array}{c}0.0022^{* * *} \\
(0.0008)\end{array}$ & $\begin{array}{c}0.0004 \\
(0.0006)\end{array}$ & $\begin{array}{c}0.0010 \\
(0.0007)\end{array}$ & $\begin{array}{c}0.0007 \\
(0.0004)\end{array}$ \\
\hline Academic & $\begin{array}{c}0.0021^{* * *} \\
(0.0005)\end{array}$ & $\begin{array}{c}0.0013^{* * *} \\
(0.0004)\end{array}$ & $\begin{array}{c}0.0016^{* * *} \\
(0.0005)\end{array}$ & $\begin{array}{c}0.0009^{* * *} \\
(0.0003)\end{array}$ \\
\hline Female & $\begin{array}{l}-0.0011 \\
(0.0010)\end{array}$ & $\begin{array}{l}-0.0001 \\
(0.0008)\end{array}$ & $\begin{array}{c}-0.0015^{* *} \\
(0.0007)\end{array}$ & $\begin{array}{c}-0.0009^{* *} \\
(0.0004)\end{array}$ \\
\hline Industry experience & $\begin{array}{l}-0.0001 \\
(0.0000)\end{array}$ & $\begin{array}{l}-0.0000 \\
(0.0000)\end{array}$ & $\begin{array}{l}-0.0000 \\
(0.0000)\end{array}$ & $\begin{array}{c}-0.0000^{*} \\
(0.0000)\end{array}$ \\
\hline Founding experience & $\begin{array}{c}-0.0018^{* *} \\
(0.0009)\end{array}$ & $\begin{array}{l}-0.0008 \\
(0.0007)\end{array}$ & $\begin{array}{c}0.0009 \\
(0.0007)\end{array}$ & $\begin{array}{c}0.0000 \\
(0.0005)\end{array}$ \\
\hline Failure experience & $\begin{array}{c}0.0020 \\
(0.0013)\end{array}$ & $\begin{array}{c}0.0006 \\
(0.0008)\end{array}$ & $\begin{array}{c}0.0006 \\
(0.0014)\end{array}$ & $\begin{array}{c}0.0001 \\
(0.0006)\end{array}$ \\
\hline Opportunity driven & $\begin{array}{c}0.0023^{* * *} \\
(0.0007)\end{array}$ & $\begin{array}{c}0.0007 \\
(0.0006)\end{array}$ & $\begin{array}{c}0.0005 \\
(0.0007)\end{array}$ & $\begin{array}{c}0.0002 \\
(0.0004)\end{array}$ \\
\hline$R \& D$ & $\begin{array}{c}0.0034^{* * *} \\
(0.0006)\end{array}$ & $\begin{array}{c}0.0026^{* * *} \\
(0.0005)\end{array}$ & $\begin{array}{l}0.0013^{* *} \\
(0.0006)\end{array}$ & $\begin{array}{c}0.0004 \\
(0.0004)\end{array}$ \\
\hline Patent & $\begin{array}{c}0.0034 \\
(0.0025)\end{array}$ & $\begin{array}{c}0.0004 \\
(0.0013)\end{array}$ & $\begin{array}{c}0.0006 \\
(0.0018)\end{array}$ & $\begin{array}{c}0.0004 \\
(0.0008)\end{array}$ \\
\hline Obs. & 25410 & & & \\
\hline
\end{tabular}

Standard errors in parentheses, clustered at the firm level.

Year, industry and region fixed effects, and firm controls included.

${ }^{*} p<0.10,{ }^{* *} p<0.05,{ }^{* * *} p<0.01$

Table A.11: Correlations of seemingly unrelated regression results (after matching)

\begin{tabular}{lc}
\hline GVC $\times B A$ & $0.4757^{* * *}$ \\
GVC $\times I V C$ & $(0.0893)$ \\
& $0.2934^{* * *}$ \\
GVC $\times C V C$ & $(0.0733)$ \\
& $0.2283^{* * *}$ \\
BA $\times I V C$ & $(0.0694)$ \\
& $0.2739^{* * *}$ \\
BA $\times C V C$ & $(0.0753)$ \\
& $0.4054^{* * *}$ \\
IVC $\times C V C$ & $(0.0999)$ \\
& $0.2490^{* *}$ \\
\hline Obs. & $(0.1117)$ \\
\hline Standard errors in parentheses, clustered at the firm level. & 25410 \\
${ }^{*} p<0.10,{ }^{* *} p<0.05,{ }^{* * *} p<0.01$ &
\end{tabular}


Table A.12: $\mathrm{Chi}^{2}$-tests for equality of subsidy coefficients

\begin{tabular}{lccc}
\hline & $\mathrm{Chi}^{2}$ & df & p-value \\
\hline GVC:Subsidy(t) vs. BA:Subsidy(t) & 1.21 & 1 & 0.27 \\
GVC:Subsidy(t) vs. IVC:Subsidy(t) & 7.43 & 1 & 0.01 \\
GVC:Subsidy(t) vs. CVC:Subsidy(t) & 5.09 & 1 & 0.02 \\
\hline & $\mathrm{Chi}^{2}$ & df & p-value \\
\hline BA:Subsidy(t) vs. IVC:Subsidy(t) & 3.80 & 1 & 0.05 \\
BA:Subsidy(t) vs. CVC:Subsidy(t) & 3.71 & 1 & 0.05 \\
\hline
\end{tabular}

\section{Additional Figures}

Figure A.1: Estimated probability for subsidy receipt before and after matching
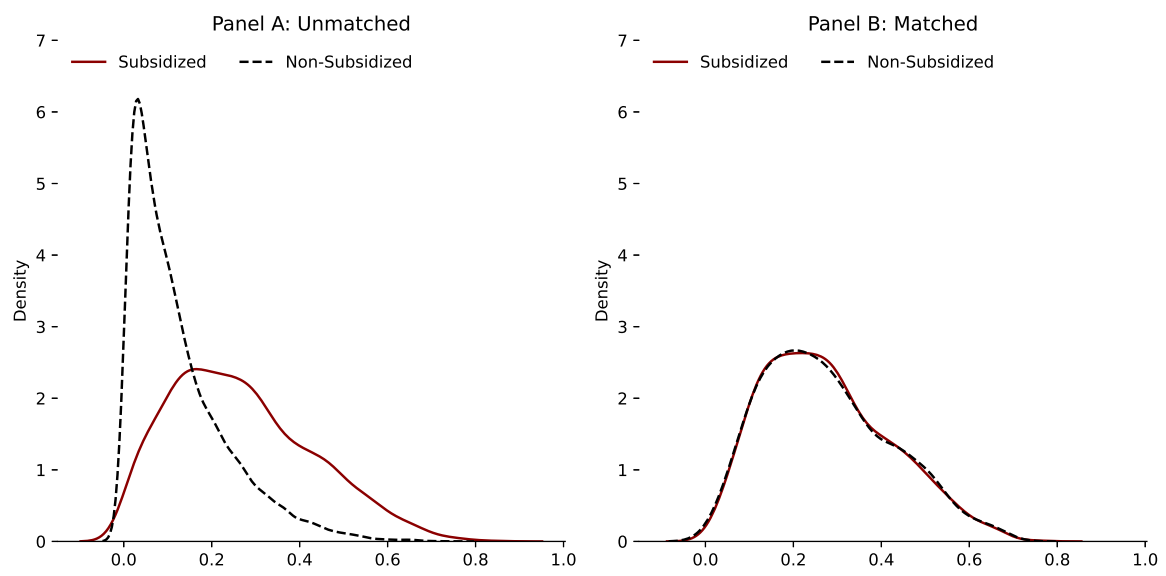

Notes: Panel $\boldsymbol{A}$ shows the kernel density estimates for the estimated probability of receiving a subsidy for the group of startups that have in fact received a subsidy (red line) and those that have not (black dashed line) before matching. Panel $\boldsymbol{B}$ shows the the same estimates weighted by the balancing weights obtained from the matching procedure described in section B. Kernel densities are estimated using a Gaussian kernel, the bandwidth is calculated using Scott's Rule, i.e $n(-1 /(d+4))$, where $n$ is the number of data points, and d the dimension of the data. For the weighted kernel density estimates, the effective number of data points $n_{\text {eff }}=\sum_{i}\left(w_{i}\right)^{2} / \sum_{i}\left(w_{i}^{2}\right)$ is used, where $w_{i}$ is the weight of data point $i$. 


\section{Appendix References}

Bersch, J., Gottschalk, S., Müller, B. and Niefert, M. (2014), 'The Mannheim Enterprise Panel (MUP) and firm statistics for Germany', ZEW-Centre for European Economic Research Discussion Paper (14-104).

Bertoni, F. and Martí, J. (2011), 'Financing entrepreneurial ventures in europe: The vico dataset', Available at SSRN 1904297.

Fryges, H., Gottschalk, S. and Kohn, K. (2009), 'The KfW/ZEW start-up panel: design and research potential', ZEW-Centre for European Economic Research Discussion Paper (09-053).

Hottenrott, H. and Richstein, R. (2020), 'Start-up subsidies: Does the policy instrument matter?', Research Policy 49(1), 103888.

Hsu, D. K., Haynie, J. M., Simmons, S. A. and McKelvie, A. (2014), 'What matters, matters differently: a conjoint analysis of the decision policies of angel and venture capital investors', Venture Capital 16(1), 1-25.

Iacus, S. M., King, G. and Porro, G. (2011), 'Multivariate matching methods that are monotonic imbalance bounding', Journal of the American Statistical Association 106(493), 345-361.

Iacus, S. M., King, G. and Porro, G. (2012), 'Causal inference without balance checking: Coarsened exact matching', Political analysis 20(1), 1-24.

Lerner, J. and Nanda, R. (2020), 'Venture capital's role in financing innovation: What we know and how much we still need to learn', Journal of Economic Perspectives 34(3), 23761.

Tykvová, T. (2018), 'Venture capital and private equity financing: an overview of recent literature and an agenda for future research', Journal of Business Economics 88(3-4), 325362. 
Download ZEW Discussion Papers from our ftp server:

http://ftp.zew.de/pub/zew-docs/dp/

or see:

https://www.ssrn.com/link/ZEW-Ctr-Euro-Econ-Research.html

https://ideas.repec.org/s/zbw/zewdip.html

$$
\text { // }
$$

IMPRINT

ZEW - Leibniz-Zentrum für Europäische Wirtschaftsforschung GmbH Mannheim

ZEW - Leibniz Centre for European

Economic Research

L 7,1 68161 Mannheim · Germany

Phone +49621 1235-01

info@zew.de·zew.de

Discussion Papers are intended to make results of ZEW research promptly available to other economists in order to encourage discussion and suggestions for revisions. The authors are solely responsible for the contents which do not necessarily represent the opinion of the ZEW. 